\title{
URGENSI ILMU MUKHTALIF AL-HADITS DALAM IJTIHAD: TELAAH ATAS HUKUM MENJAMA' DAN MENGQADHA SHALAT Rubiyanah $^{1}$, Abdul Jalil ${ }^{2}$
}

${ }^{1}$ Fakultas IImu Dakwah dan IImu Komunikasi UIN Syarif Hidayatullah Jakarta

${ }^{2}$ Badan Litbang dan Diklat Kementerian Agama

${ }^{1}$ rubiyanah@uinjkt.ac.id, ${ }^{2}$ abduljalil.ruby@gmail.com

\begin{abstract}
Abstrak
Penelitian ini mengkaji hadis yang menjelaskan tentang menjama' shalat tanpa halangan dan mengqadhanya bagi yang meninggal. Penelitian ini bertujuan untuk mengetahui bagaimana hukum dan cara menjama' shalat tanpa halangan, dan mengqadhanya bagi yang meninggal berdasarkan keterangan hadis-hadis, serta analisis ulama fiqh. Metode yang digunakan adalah tahlili dan muqarin, yaitu melakukan analisis terhadap hadis-hadis yang bertentangan makna zhahirnya, kemudian dikomparasikan antara hadis-hadis tersebut dengan mengacu pada ilmu mukhtalif al-hadits. Tokoh-tokoh yang menggunakan metode tahili antara lain: Ibn Hajar al'Atsqalaniy, Al-'Abbas Syihab al-Din Ahmad bin Muhammad al-Qastalani, Syams al-Din Muhammad bin Yusuf bin 'Ali al-Kirmani, Muhammad bin 'Abd al-Baqi' bin Yusuf al-Zarqani. Sedangan yang menggunakan metode muqarin adalah Imam Nawawi dan Badr al-Din Abu Muhammad Mahmud bin Ahmad. Perbedaan pendapat di kalangan ulama fiqh (khilafiyah), disebabkan tidak ada penjelasan secara qath'i baik dalam al-Qur'an maupun Sunnah. Dari sinilah terjadi ijtihad ulama yang kebenarannya relatif (zhanniy). Dalam perihal hukum menjama' shalat tanpa halangan, dan mengqadhanya bagi yang meninggal ditemukan hadis-hadis yang makna zhahirnya saling bertentangan. Ilmu mukhtalif al-hadits adalah solusi dalam ijtihad untuk mengkompromikan dan mendapatkan kesimpulan hukum. Output dari penelitian ini memberikan kontribusi positif bagi umat Islam untuk memperoleh kejelasan hukum sebagai acuan amaliah secara praktis.
\end{abstract}

Kata Kunci: Ilmu Mukhtalif al-Hadits, Shalat, litihad, Khilafiyah

\section{Abstract}

[URGENCY OF THE SCIENCE OF MUKHTALIF AL HADITH IN IJTIHAD: STUDY THE LAW OF JAMA 'AND QADHA PRAYER]. This study examines the hadith which explains about praying without hindrance and reciting it for the dead. This research aims to find out how the law and how to perform 'prayers without hindrance, and compare it for the deceased based on the evidence of hadiths, as well as the analysis of figh scholars. The method used is tahlili and muqarin, which is to analyze the hadiths that contradict the explicit meaning, then compared between the hadiths with reference to the science of mukhtalif al-hadith. Figures using the tahili method include: Ibn Hajar al-'Atsqalaniy, Al-'Abbas Syihab al-Din Ahmad bin Muhammad al-Qastalani, Syams al-Din Muhammad bin Yusuf bin 'Ali al-Kirmani, Muhammad bin' Abd al-Baqi 'bin Yusuf al-Zarqani. Those who use the method of muqarin are Imam Nawawi and Badr al-Din Abu Muhammad Mahmud bin Ahmad. Differences of opinion among the scholars of figh (khilafiyah), because there is no explanation in qath'i both in the Qur'an and Sunnah. From here comes the ijtihad of scholars whose truth is relative (zhanniy). In the matter of the law of praying 'prayers without hindrance, and it's qadha for the dead are found hadiths whose meaning zhahirnya contradict each other. The science of mukhtalif al-hadith is a solution in ijtihad to compromise and get legal conclusions. The output of this study makes a positive contribution for Muslims to obtain legal clarity as a practical reference in practice.
\end{abstract}

Keywords: Knowledge of Mukhtalif al-Hadith, Prayer, litihad, Khilafiyah

This work is licensed under a Creative Commons Attribution-NonCommercial 4.0 International Licens 


\section{PENDAHULUAN}

$\mathcal{H}$ adis merupakan pernyataan, pengamalan, taqrir dan hal ihwal Rasulullah saw yang menjadi sumber kedua ajaran Islam setelah al-Qur'an (Ismail, 1988: 3). Setiap Muslim wajib mengikuti dan mengamalkan ajaran-ajaran yang terdapat di dalamnya. Karena itu, mempelajari hadis juga merupakan keharusan, sebab untuk beramal yang terdapat dalam hadis-hadis Nabi, seseorang minimal mengetahui hal-hal yang diajarkan di dalam hadis-hadis itu. Misalnya perihal yang berkaitan dengan kebolehan menjama' dan mengqadha shalat, penjelasannya harus berasal dari sumber yang jelas, yaitu hadis sebagai dasar hukum atau hujah agama. Di sinilah hadis memiliki posisi sebagai penjelas alQur'an (mubayyin al-Qur'an) yang memuat ajaran-ajaran yang bersifat global.

Hadis yang periwayatannya secara mutawatir memiliki kedudukan yang sama dengan al-Qur'an, yaitu qath'iy al-wurud (mutlak kebenaran sumbernya) dan qath'iy al-dilalah (mutlak kebenaran makna dan konotasinya). Berbeda dengan hadis yang periwayatannya secara ahad, masih diperlukan penelitian tentang validitas sumber dan keaslian maknanya dengan bantuan ilmu-ilmu hadis. Oleh karena itu, validitas sumber dan otoritas kebenaran hadis ahad adalah zhanniy al-wurud (relatif kepastian asal dan sumbernya) dan zhanniy aldilalah (relatif kepastian konotasinya) (Yusqi, 2010: 16). Dengan demikian, hadis-hadis ahad menjadi objek penelitian ulama ahli hadis, sedangkan hadis yang berkategori mutawatir tidak menjadi objek penelitian, sebab tidak diragukan lagi kesahihannya berasal dari Rasulullah saw (Ismail, 1988: 4).

Hadis ahad adalah hadis yang diriwayatkan oleh sejumlah periwayat yang tidak mencapai tingkat mutawatir (al-Khatib, 1989: 302). Menurut Sa'id Ramadhan al-Buthi, hadis ahad ialah hadis yang sanadnya shahih dan bersambung sampai kepada Rasulullah saw, tetapi kandungannya memberikan pengertian zhanni dan tidak sampai kepada qath'i (yakin) (al-Buthi, tth: 17).
Istilah yang lazim digunakan dalam penelitian hadis, sehingga dapat ditentukan shahih atau tidaknya suatu hadis biasa disebut takhrij al-hadits. Bagi para peneliti, takhrij alhadits ini sangat penting, karena penelitian dalam melacak asal-usul riwayat hadis yang akan diteliti akan mengalami kesulitan tanpa takhrij al-hadits. Al-Nawawiy (wafat 676 H/1277 M) menyatakan, jika sanad hadis berkualitas shahih, maka hadis itu dapat diterima, sedangkan jika tidak shahih, maka harus ditinggalkan. Keterkaitan hadis dengan sanadnya ibarat hubungan antara hewan dengan kakinya (alNawawiy, tth: 88).

Senada dengan pandangan al-Nawawiy, Ibn Khaldun (wafat 808 H/1406 M) mengungkapkan bahwa ulama hadis yang melakukan penelitian berita yang berkenaan dengan agama berpegang pada penelitian terhadap pembawa berita (rawi). Apabila para pembawa berita adalah orang-orang yang dapat dipercaya, maka berita itu dinyatakan berkualitas shahih. Sebaliknya, apabila para pembawa beritanya bukan orangorang yang dapat dipercaya, maka berita yang bersangkutan tidak dapat dijadikan hujah agama. Di samping keshahihan sanad hadis, juga tidak mengabaikan pentingnya penelitian matan hadis. Salah satu syarat yang harus dipenuhi oleh hadis yang berkualitas shahih, yaitu sanad dan matan hadis harus terhindar dari kejanggalan (syadz) dan cacat ('illat) (Ismail, 1988: 5).

Penelitian ini mengkaji hadis yang menjelaskan tentang menjama' shalat tanpa halangan dan mengqadhanya bagi yang meninggal. Untuk mengetahui apakah hadis tersebut shahih dan dapat menjadi dasar hukum, maka diperlukan penelitian terhadap kesahihan sanad hadis. Dalam penelitian ini, perumusan masalahnya adalah "bagaimana hukum menjama' shalat tanpa halangan ('udzur), dan mengqadhanya bagi yang meninggal menurut keterangan hadis?" Tujuan penelitian ini, untuk mengetahui bagaimana hukum menjama' shalat tanpa halangan ('udzur), dan mengqadhanya 
bagi yang meninggal berdasarkan penjelasan hadis?

\section{KAJIAN TEORETIS}

ljtihad melibatkan pemahaman seorang ulama terhadap suatu dalil hukum, baik dalil hukum itu bersumber dari al-Qur'an maupun hadis untuk memperoleh kesimpulan hukum yang merupakan output dari proses ijtihad tersebut. Output yang dihasilkan seringkali berbeda antara satu ijtihad dengan ijtihad yang lain, tergantung bagaimana cara mengolah inputnya itu sendiri. Cara mengolah input inilah yang seringkali menjadi faktor timbulnya perbedaan hukum dalam suatu masalah. Termasuk ketika ada suatu input berupa hadis atau atsar di mana ada dua hadis atau atsar yang berkaitan dengan suatu masalah, namun keduanya mempunyai kontradiksi makna secara lahir (dzahir), atau dalam ilmu hadis dikenal dengan istilah mukhtalif al-ahadits atau musykil al-atsar.

Perlu ditegaskan, di dalam hadis tidak mungkin terjadi kontradiksi, karena hadis merupakan sabda Rasulullah saw dan menjadi salah satu sumber hukum (mashdar al-tasyri') dalam agama Islam. Apa yang disabdakan Rasul semata-mata adalah wahyu dari Allah SWT (QS al-Najm/53:3-4). Adapun kontradiksi yang dimaksud di sini adalah kontradiksi makna jika dilihat secara lahirnya saja. Namun jika diteliti lebih dalam, kontradiksi itu akan hilang dengan sendirinya. Ibn Khuzaimah pernah berkata, "aku tidak pernah mengetahui ada dua hadis yang diriwayatkan dari Rasulullah saw, dengan sanad yang sama-sama shahih namun maknanya saling bertentangan. Jika ada orang yang mengetahuinya, berikanlah kepadaku, niscaya akan aku padukan keduanya" (Wahab, 2014).

Praktik pengolahan input seperti ini tidak dapat dilakukan oleh sembarang orang tanpa memiliki kompetensi keilmuan. Orang yang hendak melakukan hal itu harus menguasai minimal dua bidang ilmu sekaligus, yaitu ilmu hadis dan ilmu fiqih. Kedua disiplin ilmu tersebut mempunyai kaitan yang sangat erat satu sama lain. Keterkaitan ilmu hadis dan ilmu fiqh diungkapkan Al-A'masy salah seorang ahli hadis dari kalangan tabi' in di tengah perbincangannya dengan Imam Abu Hanifah, "wahai para ahli fiqih! kalian adalah dokter, dan kami (ahli hadis) adalah apoteker" (Wahab, 2014).

Dalam ilmu mukhtalaf al-hadits, terdapat rumusan beberapa cara ketika menyikapi hadishadis yang bertentangan, antara lain adalah dengan al-jam'u (memadukan/mencari titik temu), al-tarjih (mencari yang paling kuat/dominan), dan ma'rifah al-nasikh wa almansukh (mengetahui mana yang menasakh dan mana yang dimansukh) (Wahab, 2014).

Dalam tinjauan bahasa Arab, mukhtalif alhadits adalah susunan dua kata, yakni mukhtalif dan al-hadits. Menurut bahasa, mukhtalif ialah isim fa'il dari ikhtilaf (berbeda) yang merupakan lawan dari ittifaq (sesuai). Secara etimologis, mukhtalif al-hadits berarti hadis-hadis yang berbeda dalam makna antara satu sama lain, yaitu maknanya saling bertentangan. Sedangkan menurut istilah (terminologis):

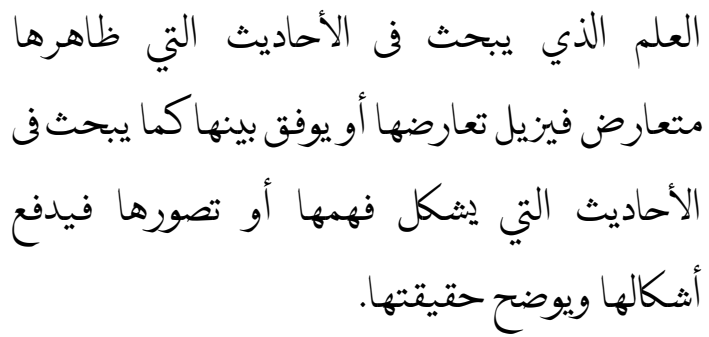

“Ilmu yang membahas hadis-hadis yang tampaknya saling bertentangan, lalu menghilangkan pertentangan itu atau mengkompromikannya, di samping membahas hadis yang sulit difahami atau dimengerti, lalu menghilangkan kesulitan itu dan menjelaskan hakikatnya" (Khayyath, 2001: 25).

Definisi tersebut dikuatkan oleh Mahmud al-Thahhan, mukhtalif al-hadits ialah:

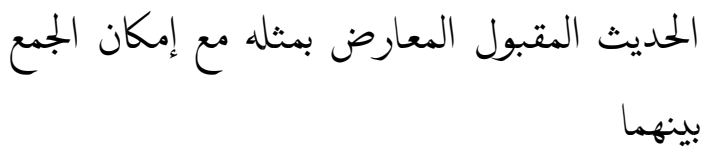

“Hadis maqbul yang saling bertentangan dengan yang semisalnya, sehingga kemungkinan kedua hadis tersebut dapat dikompromikan" (alThahhan, 1405: 46).

Ilmu mukhtalif al-hadits disebut oleh sebagian ulama dengan sebutan ilmu musykil alhadits, ilmu ikhtilaf al-hadits, ilmu ta'wil alhadits, dan talfiq al-hadits. Menurut al-Suyuthi, hadis-hadis mukhtalif adalah dua buah hadis yang saling bertentangan pada makna zhahirnya. Karena itu, di antara keduanya dikompromikan atau ditarjih salah satunya. Ilmu 
ini merupakan sebuah pengetahuan antara hadis dan fiqh, sehingga sampai kepada kesimpulan yang benar (al-Suyuthi, 1992: 310).

Perbedaan pandangan di antara ulama dalam mempertimbangkan cara yang paling tepat untuk diprioritaskan, dan yang lebih mungkin untuk diaplikasikan dalam menyikapi hadis-hadis yang bertentangan itu, berimplikasi dalam pengambilan kesimpulan hukum sesuai cara yang ditempuh oleh masing-masing ulama tersebut. Hal ini membuat perbedaan-perbedaan hukum dalam satu masalah di dalam koridor masalah-masalah fiqh (masail fiqhiyyah) menjadi sangat wajar adanya.

\section{METODE PENELITIAN}

Penelitian yang dilakukan dalam tulisan ini adalah penelitian kepustakaan (library research). Pendekatan yang dipilih dalam penelitian ini adalah pendekatan ilmu hadis. Dalam ilmu hadis, dikenal beberapa corak atau metode pemahaman hadis, yakni metode tahlili (analitis), metode ijmali (global), metode muqarin (komparatif), dan metode maudhu'i (tematis) (Ali, 2001: 28).

Metode tahlili adalah memahami hadishadis Rasulullah saw dengan memaparkan segala aspek yang terkandung di dalam hadis-hadis yang dipahami, serta menerangkan maknamakna yang tercakup di dalamnya sesuai dengan keahlian dan kecenderungan pensyarah yang memahami hadis-hadis tersebut (Buchari M., 1999: 26).

Metode ijmali adalah menjelaskan hadishadis secara ringkas, tetapi dapat merepresentasikan makna literal hadis dengan Bahasa yang mudah dimengerti (Buchari M., 1999: 37). Ciri metode ijmali terlelak pada pola atau sistematika pembahasan, bukan pada jumlah hadis-hadis yang disyarahkan.

Metode muqarin adalah metode memahami hadis dengan cara: membandingkan hadis yang memiliki redaksi yang sama atau mirip dalam kasus yang sama, atau memiliki redaksi yang berbeda dalam kasus yang sama; membandingkan berbagai pendapat ulama syarah dalam mensyarah hadis (Buchari M., 1999: 47).

Metode maudhu'i adalah memahami hadis dengan cara menghimpun hadis yang membicarakan tentang topik atau permasalahan yang sama, kemudian memahami hadis tersebut secara tematik (al-'Ainiy, 1972: 24). Meskipun metode ini lebih populer di kalangan ahli tafsir, namun diterapkan pula untuk memahami hadis.

Metode yang dipilih untuk kajian ini adalah tahlili dan muqarin, karena kedua metode itu sangat relevan untuk melakukan analisis terhadap hadis-hadis yang bertentangan makna zhahirnya, kemudian dikomparasikan antara hadis-hadis tersebut dengan mengacu pada ilmu mukhtalif al-hadits.

Di antara kitab-kitab Syarah hadis yang menggunakan metode tahlili adalah: Fath alBari bi Syarh al-Bukhariy karya Ibn Hajar al'Atsqalaniy, Irsyad al-Sari li Syarh Shahih alBukhariy karya Al-'Abbas Syihab al-Din Ahmad bin Muhammad al-Qastalani, Al-Kawakib alDarar fi Syarh Shahih al-Bukhariy karya Syams al-Din Muhammad bin Yusuf bin 'Ali al-Kirmani, Syarh al-Zarqani 'ala Muwatta' al-Imam Malik karya Muhammad bin 'Abd al-Baqi' bin Yusuf alZarqani.

Di antara kitab-kitab Syarah hadis yang menggunakan metode muqarin adalah: Shahih Muslim bi Syarh al-Nawawiy karya Imam Nawawi, 'Umdah al-Qari Syarh Shahih alBukhariy karya Badr al-Din Abu Muhammad Mahmud bin Ahmad.

\section{TEMUAN DAN PEMBAHASAN}

\section{Temuan}

Shalat merupakan salah satu ibadah yang dalam pelaksanaannya memiliki waktu yang telah ditentukan (kitaban mauqutan) (QS alNisa'/4:103). Untuk melaksanakan shalat tepat waktu, terkadang ada faktor-faktor yang menyulitkan (masyaqqah). Ajaran Islam memberikan rukhshah (keringanan) kepada umat Islam untuk menjama' shalat, yakni menggabungkan dua shalat (zhuhur dan 'Ashar atau Maghrib dan 'Isya') yang dikerjakan dalam waktu salah satunya. Menjama' shalat boleh dilakukan dengan cara jama' taqdim atau jama' ta'khir.

Jama' taqdim adalah menggabungkan dua shalat, dan dikerjakan pada waktu shalat pertama dengan dilakukan secara berurutan. Adapun jama' ta'khir adalah menggabungkan 
dua shalat, dan dikerjakan pada waktu shalat kedua. Pelaksanaan jama' ta'khir boleh dilakukan secara berurutan, dan boleh juga tidak berurutan. Tetapi melakukan secara berurutan dinilai lebih utama (Tim Baitul Kilmah, 2017: 288). Shalat Shubuh tidak boleh dijama', baik jama' taqdim maupun jama' ta'khir. Ia merupakan shalat yang independen (mustaqill), sehingga pelaksanaanya harus sesuai dengan waktu yang telah ditentukan.

Kebolehan menjama' shalat bagi seorang Muslim, bukan tanpa sebab. Jumhur ulama menetapkan, safar (perjalanan) merupakan salah satu sebab dibolehkannya menjama' shalat. Terlepas dari perbedaan pandangan mengenai macam dan cara perjalanan itu dilaksanakan. Imam Malik (wafat 179 H/800 M) menyebutkan, perjalanan yang membolehkan untuk menjama' shalat, harus ada indikasi masyaqqah (berat) jika melaksanakan shalat sesuai dengan waktunya. Berbeda dengan Imam Syafi'i (wafat 204 H/820 M), tidak mengharuskan perjalanan tersebut menimbulkan masyaqqah (al-Qurtubiy, tth: 125).

Dalam menyikapi tentang jenis perjalanan, ulama fiqh berbeda pendapat. Sebagian menyatakan bahwa perjalanan yang dimaksudkan adalah perjalanan dalam rangka ibadah, misalnya ibadah haji dan jihad. Sebagian yang lain menyatakan bahwa perjalanan yang dimaksud adalah perjalanan ibadah, bukan perjalanan maksiat. Silang pendapat ini disebabkan oleh adanya perbedaan dalam menetapkan jenis perjalanan yang mengabaikan kebolehan qashar shalat. Sekalipun dalam masalah ini terdapat sifat 'am (umum), lantaran masalah qashar shalat sudah diriwayatkan dari Rasulullah saw, yang terdiri dari ucapan (qaulan) dan perbuatan (fi'lan).

Dalam masalah menjama' shalat, yang ada hanya riwayat tentang perbuatan saja (fi'lan). Bagi ulama yang membatasi kebolehan jama' hanya dalam perjalanan yang pernah dilakukan Rasulullah saw, maka mereka ini melarang pelaksanaan jama' dalam perjalanan yang lainnya. Bagi ulama yang menganggap adanya rukhshah bagi musafir untuk melakukan jama', berarti rukhshah ini berlaku pula untuk jenis perjalanan yang lainnya (al-Qurtubiy, tth: 125).

Sedangkan qadha ialah mengerjakan kewajiban setelah keluar dari waktu yang ditentukan. Mengqadha shalat berarti mengerjakan shalat setelah habisnya waktu. Secara agama dan logika, sudah semestinya seorang Muslim melaksanakan shalat pada waktunya (Az-Zuhaili, 2010: 271). Qadha shalat diwajibkan bagi siapa pun yang meninggalkan shalat, baik sengaja maupun tidak. Untuk orang yang meninggalkan shalat secara sengaja, diwajibkan mengqadha shalat secepat mungkin (faur). Bahkan ia diharuskan mengerjakan shalat qadha terlebih dahulu, sebelum mengerjakan shalat wajib lainnya atau shalat sunah. Misalnya, ketika ada yang secara sengaja meninggalkan shalat dzuhur dan waktunya sudah habis, ia diwajibkan untuk mengqadhanya sebelum menunaikan shalat ashar. Beda halnya dengan orang yang lupa atau ketiduran, mereka dianjurkan untuk menyegerakan (wa yubadiru bihi nadban), dan tidak diwajibkan sebagaimana halnya orang yang meninggalkan shalat dengan sengaja (al-Dimyatihi, tth: 23).

Ulama telah sepakat bahwa mengqadha shalat adalah wajib bagi orang yang lupa atau tertidur (al-nasiy wa al-na'im). Ini didasarkan pada keterangan hadis yang dikutip al-Sayyid Sabiq (Sabiq, 1981: 231).

$$
\begin{aligned}
& \text { إنه ليس فى النوم تفريط إنما التفريط فى اليقظة، فإذا } \\
& \text { ني أحد صلاة أو نام عنها فليصلها إذا ذكرها. }
\end{aligned}
$$
tertidur. Kelalaian itu ialah di waktu bangun. Maka apabila seseorang itu lupa shalat atau tertidur, hendaklah ia melakukannya jika telah ingat atau sadar."

Abd al-Razak (wafat $211 \mathrm{H}$ ) eriwayatkan dari Nafi' (wafat $169 \mathrm{H}$ ), bahwa Ibn 'Umar (wafat $73 \mathrm{H} / 692 \mathrm{M}$ ) pada suatu ketika jatuh sakit hingga pingsan dan meninggalkan shalat. Setelah sadar, ia tidak melakukan shalat yang ketinggalan itu. Terdapat pula penjelasan dari Ibn Juraij (wafat 150 H/767 M), dari Ibn Thawus (wafat $664 \mathrm{H} / 1266 \mathrm{M}$ ), dari ayahnya: "seseorang yang jatuh sakit hingga pingsan, kemudian sadarkan diri, tidaklah perlu mengulangi shalatnya." Hasan al-Bashri (wafat $110 \mathrm{H}$ ) dan Muhammad bin Sirin (wafat 110 $\mathrm{H} / 729 \mathrm{M}$ ) mengatakan, orang yang pingsan tidak perlu mengulangi shalat yang ketinggalan selama ia pingsan (Sabiq, 1981: 231-232). 
Adapun orang yang meninggalkan shalat dengan sengaja, menurut jumhur ulama ia berdosa dan wajib mengqadhanya. Pendapat ini berbeda dengan Ibn Taimiyah yang menyatakan, orang yang sengaja meninggalkan shalat tidaklah diperintah oleh syara' untuk mengqadha, dan jika shalat yang ditinggalkan dengan sengaja itu diqadha juga, maka shalatnya tidak sah. Sebagai ganti dari shalat yang ditinggalkan, yang bersangkutan harus memperbanyak shalat sunnah (al-tathawwu') (Sabiq, 1981: 232). Ibn Hazm menguatkan pandangan Ibn Taimiyah, orang yang meninggalkan shalat dengan sengaja sampai luput waktunya, maka shalat tersebut tidak dapat diqadha untuk selama-lamanya. Oleh sebab itu, hendaklah ia banyak mengerjakan kebaikan (min fi'l al-khair), mengerjakan shalatshalat sunnah, serta bertaubat dan beristighfar, agar timbangan amal kebajikannya di hari Kiamat nanti lebih berat (QS al-Qari'ah/101:6-7; Sabiq, 1981: 232).

\section{Pembahasan}

Hadis yang ditakhrij riwayat Abu Daud, nomor indeks 1025, sebagai berikut:

$$
\text { مدثثا عثمان بن أبي شيبة حدثنا أبو معاوية حدثنا }
$$

Telah menceritakan kepada kami Utsman bin Abu Syaibah, telah menceritakan kepada kami Abu Mu'awiyah, telah menceritakan kepada kami alA'masy dari Habib bin Abu Tsabit dari Sa'id bin Jubair dari Ibn 'Abbas ia berkata; "Rasulullah saw pernah menjama' shalat Zhuhur dan Ashar, antara shalat Maghrib dan 'Isya' di Madinah, tidak dalam kondisi ketakutan, tidak pula hujan." Maka ditanyakan hal itu kepada Ibn "Abbas; "Apa maksud Rasulullah saw melakukan hal itu?" Ibn 'Abbas menjawab; "supaya tidak memberatkan umatnya" (Riwayat Abu Daud).

Hadis tersebut juga diriwayatkan al-Jama'ah selain al-Bukhari dan Ibn Majah, nomor indeks
1194 (Ash Shiddieqy, 2001: 389-390). Intinya bahwa menjama' shalat tanpa halangan ('udzur) adalah dibolehkan. Menurut al-Baghawi (wafat $516 \mathrm{H} / 1122 \mathrm{M}$ ), yang menjadi 'illat Rasulullah saw berbuat demikian, yaitu memberikan kemudahan kepada umat Islam (QS alBaqarah/2:185). Sebagian ulama membolehkan menjama' shalat bagi mukimin tanpa halangan ('udzur), dengan syarat tidak dijadikan kebiasaan untuk dilakukan. Di antara ulama yang berpendapat seperti itu antara lain: Ibn Sirin (wafat 110 H/729 M), Rabi'ah (wafat 139 H/753 M), Ibn al-Mundzir $(318 \mathrm{H})$, al-Qaffal al-Kabir (wafat 365 H/976 M), dan diceritakan pula oleh al-Khaththabiy (wafat $388 \mathrm{H}$ ), bahwa pendapat bolehnya menjama' shalat tanpa halangan juga dari sekelompok kalangan ahli hadis (alSyaukaniy, 1421/2000: 633).

Al-Nawawiy (wafat $676 \quad \mathrm{H} / 1277 \quad \mathrm{M}$ ) mengatakan dalam Syarah Muslim, beberapa imam (jama'ah min al-aimmah) membolehkan jama' bagi orang yang tidak musafir ( $f i$ alhadhar), bila ia ada suatu kepentingan (li alhajah), asalkan hal itu tidak dijadikannya sebagai kebiasaan (li man yattakhidzuhu 'adatan). Ini juga merupakan pendapat Ibn Sirin (wafat $110 \mathrm{H} / 729 \mathrm{M}$ ) dan Asyhab (wafat 204 $\mathrm{H} / 820 \mathrm{M}$ ) dari golongan Maliki, pendapat alQaffal al-Syasyiy al-Kabir (wafat 365 H/976 M) dari golongan Syafi'i, dari Abu Ishak al-Marwazi (wafat $340 \mathrm{H}$ ), serta dari kalangan ahli hadis. Demikian diceritakan al-Khaththa>biy, dan inilah yang dipilih oleh Ibn al-Mundzir (wafat 318 H). Ibn Taimiyah (wafat 728 H/1328 M) bahkan memperluas pandangannya dengan mengutip pendapat madzhab Ahmad, yaitu membolehkan untuk menjama' shalat bagi seseorang yang sedang sibuk bekerja, sebagaimana yang diriwayatkan oleh al-Nasa'i yang marfu' bersumber kepada Rasulullah saw, sampai dibolehkannya pula menjama' shalat bagi juru masak (li al-thabakh), pembuat roti (alkhabbaz), dan orang-orang lainnya yang mengkhawatirkan hartanya menjadi rusak (miman yakhsya fasad malih) (Sabiq, 1981: 246).

Jumhur ulama berpendapat, menjama' shalat bagi mukimin tanpa 'udzur tidak dibolehkan. Mereka beralasan, bahwa menjama' shalat yang dimaksudkan dalam hadis dari Ibn 'Abbas itu ialah jama' karena sakit. Jawaban ini 
dipandang kuat oleh al-Nawawiy (wafat 676 H/1277 M). Sementara al-Hafizh Ibn Hajar al'Asqalaniy (wafat $852 \mathrm{H} / 1449 \mathrm{M}$ ) menolak argumentasi jumhur ulama. Sebab jika Rasulullah saw menjama' shalat karena sakit, tentu yang ikut shalat dengan beliau adalah orang-orang yang sakit pula (al-'Asqalaniy, 1424/2004: 29). Al-Syaukaniy (wafat 1250 $\mathrm{H} / 1834 \mathrm{M}$ ) menguatkan pendapat yang mengatakan bahwa menjama' shalat yang dilakukan Rasulullah saw di Madinah adalah "aljam' al-shuriy" (jama' shuri), yaitu jama' yang dilakukan karena ada keudzuran (al-Syaukaniy, 1421/2000: 633).

Kalangan ulama yang tidak membolehkan menjama' shalat tanpa sebab atau 'udzur syar'iy, mendasarkan pada penegasan al-Qur'an:

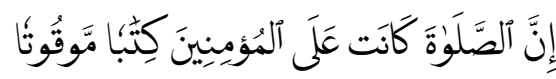

"Sesungguhnya shalat itu adalah kewajiban yang ditentukan waktunya atas orang-orang yang beriman" (QS al-Nisa'/4:103).

Asal hukum menjalankan shalat pada waktunya adalah wajib, dan suatu kewajiban hanya boleh digugurkan dengan adanya 'udzur syar'iy. Seandainya dibolehkan menjama' shalat tanpa adanya 'udzur syar'iy secara mutlak, niscaya ayat di atas tidak ada faidahnya. Tidak ada seorang ulama pun yang mengatakan bahwa mengerjakan shalat pada waktunya hanya sekadar dihukumi sunnah. Karena itu, mendirikan shalat pada waktunya masingmasing hukumnya wajib, kecuali bila ada dalil yang membolehkan untuk menjama' dengan shalat lain (Tim Baitul Kilmah, 2017: 289). Maksud hadis dari Ibn 'Abbas (wafat $68 \mathrm{H}$ ), bukan menunjukkan jama' yang sesungguhnya, tetapi mengakhirkan shalat yang pertama masih di waktunya, dan menyegerakan shalat kedua di waktu berikutnya, sehingga seakan-akan kedua shalat itu terkumpul menjadi satu (al-Syaukaniy, 1421/2000: 634).

Pandangan ini diperkuat dengan penegasan hadis:

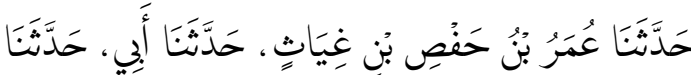

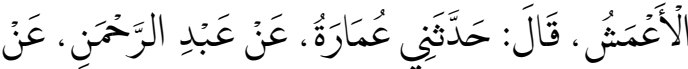

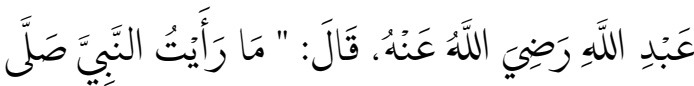

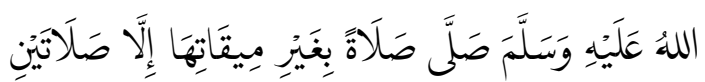

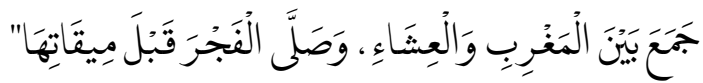
Telah menceritakan kepada kami ‘Umar bin Hafsh bin Ghiyats: telah menceritakan kepada kami ayahku: telah menceritakan kepada kami alA'masy, ia berkata: "Aku tidak pernah melihat Nabi saw melakukan shalat di luar waktunya, kecuali dua shalat. Beliau menjama' shalat Maghrib dan shalat 'Isya', serta beliau pernah shalat Shubuh sebelum waktunya" (Diriwayatkan oleh al-Bukhari nomor 1682) (al-'Asqalaniy, 1424/2004: 601).

Ibn Mas'ud (wafat $32 \mathrm{H} / 653 \mathrm{M}$ ) meniadakan semua bentuk shalat jama' yang dilakukan Rasulullah saw, kecuali menjama' shalat Maghrib dan shalat 'Isya' di Muzdalifah. Bahkan 'Umar ibn al-Khattab (wafat $23 \mathrm{H} / 644 \mathrm{M}$ ) menegaskan, menjama' shalat tanpa 'udzur termasuk di antara dosa besar. Hal ini disebutkan dalam riwayat berikut:

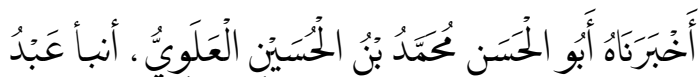

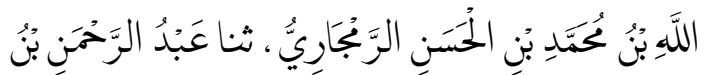

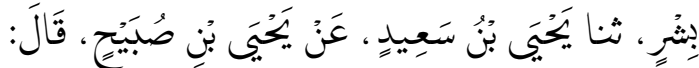

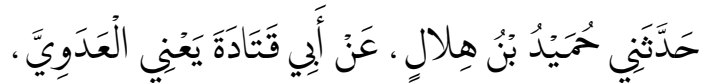

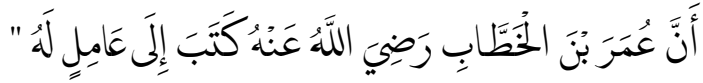

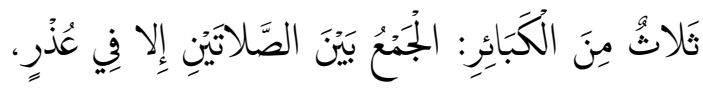

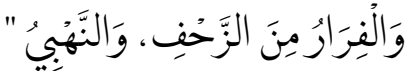
Telah memberitahukan kepada kami Abu alHasan Muhammad bin al-Husain al-'Alawiy, telah memberitakan 'Abdullah bin Muhammad bin alHasan al-Ramjariy, telah menceritakan kepada kami 'Abd al-Rahman bin Bisyr, telah menceritakan kepada kami Yahya bin Sa'id, dari Yahya bin Shubaih, ia berkata: telah menceritakan kepadaku Humaid bin Hilal, dari Abu Qatadah al-'Adawiy: bahwasanya 'Umar bin al-Khaththab radhiyallahu 'anhu pernah menulis surat untuk pegawainya: "Tiga hal termasuk dosa besar: menjama' shalat tanpa 'udzur, melarikan diri dari medan perang, dan khianat 
dalam rampasan perang" (Diriwayatkan oleh alBaihaqiy:3/169; shahih) (al-Syaukaniy, 1421/2000: 634).

\section{Analisis Kualitas Sanad Hadis}

\section{Ketersambungan Sanad}

a. Abu Daud

Abu Daud adalah mukharrij (penghimpun) hadis dengan sebuah lambang periwayatan حدثنا. Lambang ini menjelaskan bahwa metode yang digunakan adalah al-samâ', yakni antara Abu Daud dengan 'Utsmân bin Abu Syaibah sebagai gurunya terjadi persambungan sanad yang diperkuat dengan adanya lambang tersebut. Lambang itu merupakan indikasi bahwa Abu Daud mendengar langsung (liqấ) dari gurunya, 'Utsmân bin Abu Syaibah. Hal ini diperkuat dengan sejarah hidup dua perawi; Abu Daud lahir $202 \mathrm{H}$ dan wafat 275 H, sedangkan 'Utsmân bin Abu Syaibah wafat $239 \mathrm{H}$, membuktikan bahwa mereka berdua hidup sezaman (mu'ashsharah). Dengan demikian, adanya mu'ashsharah dan liqấ' antara Abu Daud dengan 'Utsmân bin Abu Syaibah benar adanya. Hal ini menunjukkan bahwa interaksi yang terjadi antara Abu Daud dengan 'Utsmân bin Abu Syaibah yang dilambangkan dengan lambang periwayatan حدثن, telah memenuhi standar dari syarat hadis shahîh. Dengan demikian, periwayatan hadis antara Abu Daud dengan 'Utsmân bin Abu Syaibah terjadi persambungan sanad (muttashil). Di samping penilaian tsiqah oleh Abd al-Rahmân bin Abu Hâtim terhadap Abu Daud. Ini menunjukkan bahwa Abu Daud merupakan perawi yang memiliki kredibilitas tinggi, sehingga riwayat yang bersumber darinya layak diterima sebagai sumber yang benar berasal dari Rasulullah saw (Mutakin, 2017: 98). b. 'Utsman bin Abu Syaibah

'Utsman bin Abu Syaibah merupakan perawi keenam (sanad pertama) dalam jalur sanad Abu Daud. Berdasarkan biografi yang dipaparkan di atas, bahwa tahun wafat 'Utsman bin Abu Syaibah adalah $239 \mathrm{H}$, sedangkan gurunya yang bernama Abu Mu'awiyah wafat $195 \mathrm{H}$. Dengan demikian, dapat dinyatakan bahwa keduanya pernah hidup semasa (mu'ashsharah). Interaksi yang dilakukan oleh 'Utsman bin Abu Syaibah terhadap Abu Mu'awiyah dilambangkan dengan حدثا, lambang ini menunjukkan bahwa metode yang dipakai adalah al-sama'. Di samping itu,
'Utsman bin Abu Syaibah juga telah menerima riwayat langsung (liqấ') dari Abu Mu'awiyah, sehingga sanad antara keduanya dinyatakan bersambung (muttashil).

Sementara itu, komentar al-Dzahabiy (wafat $748 \mathrm{H}$ ) tentang Utsman bin Abu Syaibah adalah bahwa ia hafizh. Yahya bin Ma'in (wafat $233 \mathrm{H}$ ) mengkategorikan tsiqah, begitu juga al'Ajî̂ mengatakannya sebagai tsiqah. Ibn Hibbân (wafat $342 \mathrm{H}$ ) mengelompokkannya sebagai tsiqah, dan diperkuat Ibn Hajar (wafat 852 $\mathrm{H} / 1449 \mathrm{M}$ ) yang mengatakannya sebagai tsiqah serta hafizzh. .Dengan demikian, ketsiqahannya tersebut dianggap cukup memenuhi salah satu syarat hadis shahîh. Ini juga membuktikan bahwa Utsman bin Abu Syaibah adalah seorang perawi yang memiliki kredibilitas tinggi, sehingga hadis yang diriwayatkan oleh beliau dapat diterima sebagai sumber yang berasal dari Rasulullah saw (Mutakin, 2017: 98-99).

c. Abu Mu'awiyah

Abu Mu'awiyah merupakan perawi kelima (sanad kedua) dalam jalur sanad Abu Daud. Berdasarkan biografi yang dipaparkan di atas, bahwa tahun wafat Abu Mu'awiyah adalah $195 \mathrm{H}$, sedangkan gurunya yang bernama al-A'masy wafat $147 \mathrm{H}$. Dengan demikian, dapat dinyatakan bahwa keduanya pernah hidup semasa (mu'ashsharah). Interaksi yang terjalin antara Abu Mu'awiyah dengan al-A'masy dilambangkan dengan ungkapan حدثنا. Lambang ini menunjukkan bahwa metode yang dipakai adalah al-samố, juga adanya hubungan guru murid antara keduanya. Karena itu, Abu Mu'awiyah telah menerima riwayat langsung (liqấ') dari al-A'masy, sehingga sanad antara Abu Mu'awiyah dengan al-A'masy adalah bersambung (muttashil). Di sisi lain, banyaknya ungkapan tsiqah yang disampaikan oleh para ulama serta tidak ditemukannya jarh (cacat), membuktikan bahwa Abu Mu'awiyah merupakan perawi yang berkualitas tinggi, sehingga riwayat yang bersumber darinya layak diterima sebagai sumber yang benar berasal dari Rasulullah saw. Berdasarkan itu, ketsiqahan Abu Mu'awiyah dianggap cukup memenuhi salah satu di antara syarat-syarat hadîs shahîh (Mutakin, 2017: 99 100).

d. Al-A'masy

Al-A'masy merupakan perawi keempat (sanad ketiga) dalam jalur sanad Abu Daud. 
Berdasarkan biografi yang dipaparkan di atas, bahwa tahun wafat al-A'masy adalah $147 \mathrm{H}$, sedangkan gurunya yang bernama $\mathrm{Habib}$ bin $\mathrm{Abu}$ Tsabit wafat $119 \mathrm{H}$. Dengan demikian, dapat dinyatakan bahwa keduanya pernah hidup semasa (mu'ashsharah). Lambang periwayatan yang digunakan oleh al-A'masy adalah عن. Riwayat dengan menggunakan lambang tersebut bisa dinilai bersambung, sebab selain dari history biografi, pertemuan guru murid, penilaian para kritikus yang berupa tsiqah terhadap al-A'masy, juga karena tidak ada seorang ulama kritikus hadis yang menyatakan jarh padanya. Menurut beberapa ulama, lambang عerupakan hadîs mu'an'an. Hadits ini bisa dianggap bersambung, dengan catatan bahwa hadis tersebut selamat dari tadlîs (ketidakjujuran) dan dimungkinkan adanya pertemuan dan semasa. Ini sesuai dengan apa yang diisyaratkan Imam al-Bukhârî (wafat $256 \mathrm{H}$ ), atau hanya semasa saja dengan mengikuti Imam Muslim (wafat $261 \mathrm{H}$ ). Adanya dua syarat yang ditegaskan oleh Imam alBukhârî dan Muslim serta bersihnya sifat tadlîs dari al-A'masy, maka dengan demikian riwayatnya dapat diterima (Mutakin, 2017: 99100).

e. Habîb bin Abu Tsâbit

Habîb bin Abu Tsâbit adalah perawi ketiga (sanad keempat) dalam jalur sanad Abu Daud. Lambang periwayatan yang digunakan oleh Habîb bin Abu Tsâbit adalah ع. Para ulama menilai Habîb bin Abu Tsâbit sebagai tsiqah. Tidak adanya pencelaan terhadap dirinya oleh para ulama, serta bersihnya ia dari sifat tadlîs, maka pernyataan yang mengatakan bahwa Habîb bin Abu Tsâbit menerima hadis dari Sa'îd bin Jubair dengan lambang عن dapat dipercaya. Di samping itu, berdasarkan biografi, Habîb bin Abu Tsâbit wafat tahun $119 \mathrm{H}$, serta wafat gurunya yakni Saî̀d bin Jubair $94 \mathrm{H}$, telah mengindikasaikan adanya mu'ashsharah. Hal ini berarti sanad yang ada antara Habîb bin Abu Tsâbit dengan Saî̀d bin Jubair adalah bersambung (muttashil). Banyaknya komentar tsiqah yang disampaikan oleh para ulama serta tidak ditemukannya jarh, membuktikan bahwa Habîb bin Abu Tsâbit merupakan perawi yang berkualitas tinggi, sehingga riwayat yang bersumber darinya layak diterima sebagai sumber yang benar berasal dari Rasulullah saw. Dengan demikian, ketsiqahan Habîb bin Abu
Tsâbit dianggap cukup memenuhi salah satu di antara syarat-syarat hadîs shahîh (Mutakin, 2017: 100).

\section{f. Sâîl bin Jubair}

Sa'îd bin Jubair sebagai perawi kedua (sanad kelima). Berdasarkan biografi di atas, ia wafat $94 \mathrm{H}$, sedangkan gurunya Ibn 'Abbas wafat tahun $68 \mathrm{H}$. Lambang periwayatan yang digunakan Sâ̂̂d bin Jubair adalah عن. Berdasarkan faktor kesezamanan dengan gurunya tersebut, serta pertemuan guru murid, maka sanad hadis antara Sa'îd bin Jubair dengan Ibn 'Abbas dinilai bersambung (muttashil). Sebab selain ditinjau dari sisi biografi, juga para ulama menilainya dengan tsiqah dan tidak adanya karakter mudallas terhadap Sa'îd bin Jubair. Lambang عن sebagaimana pendapat di atas, bahwa hadîs mu'an'an apabila disempurnakan dengan adanya syarat liqấ' dan mu'ashsharah serta selamat dari nilai tadlîs, maka riwayatnya bisa diterima. Sâîd bin Jubair sezaman (mu'ashsharah) dengan Ibn 'Abbas, dan selamat dari penilaian para ulama bahwa ia tidak tadlîs (Mutakin, 2017: 100-101). g. Ibn 'Abbas

Ibn 'Abbas sebagai perawi pertama (sanad terakhir), yang berdasarkan biografi terdeteksi bahwa wafatnya $68 \mathrm{H}$. Lambang periwayatan yang digunakan Ibn 'Abbas adalah قال. Jika ditinjau dari sisi biografi, ia tergolong sahabat Rasulullah saw. Para ulama tidak ada yang mencela adanya karakter mudallas terhadap Ibn 'Abbas. Dengan demikian, jika dilihat hubungan dengan Rasulullah saw, ia sebagai sahabat setia meskipun sebagai sahabat kecil, dan tidak diragukan hafalannya dalam hadis, serta kesahihan dalam menyampaikan hadis. Maka dapat dinyatakan bahwa sanad antara Ibnu 'Abbas dengan Rasulullah saw adalah bersambung (muttashil) (Mutakin, 2017: 101).

\section{Status Kualitas Sanad Hadis}

Dari uraian di atas, yang berdasarkan ketersambungan sanad dan kualitas perawi, secara keseluruhan perawi yang meriwayatkan hadis "menjama' shalat tanpa ada halangan" dalam Sunan Abu Daud nomor indeks 1025 berkualitas tsiqah, shadûq, hafîzh li al-hadîts, serta $a$ hl al-îlm. Totalitas nilai para perawi dari jalur Abu Daud serta adanya mu'ashsharah dan liqấ dapat dijadikan bukti bahwa jalur sanad Abu Daud ini bersambung (muttashil) mulai dari 
mukharrij hingga sampai kepada Rasulullah saw. Di samping itu, otentisitas sanad hadis Abu Daud nilainya menjadi kuat saat disandarkan pada riwayat-riwayat hadis dari jalur lain yang sama pembahasannya. Sebagaimana riwayat alBukhârîy, Muslim, al-Nasâ'îy, Imam Mâlik, alTirmidzîy dan Imam Ahmad.

\section{Analisis Kuantitas sanad Hadis}

Jika dilihat dari segi kuantitas perawi, hadis tentang menjama' shalat tanpa halangan menjadi hadis ahad 'aziz. Dikelompokkan hadis ahad 'aziz ini karena jumlah perawi dalam tiap tingkatannya lebih dari dua orang, yakni dua orang di tingkat sahabat, dan diteruskan dengan jumlah perawi yang banyak pada setiap tingkatannya sampai pada mukharrij hadits. Menurut al-Khithâbi, hadis tersebut menyatakan bahwa kebolehan menjama' antara dua shalat adalah ketika terdapat kepentingan/kebutuhan (ha>jah), atau adanya suatu hal asal tidak menjadi kebiasaan. Sementara sebagian ulama menakwilkan bahwa kondisi tersebut dalam keadaan sakit yang memberikan rasa berat (masyaqqah) ketika melakukan shalat sesuai dengan waktunya (al-Khitabi, tth: 264; Abadi, 2005: 608-609).

Kondisi sakit yang menjadi faktor bolehnya melaksanakan shalat jama', menurut 'Athâ' ibn Abi Rabâh (wafat 114 H/732 M) merupakan rukhshah, sehingga yang mengalaminya boleh menjama' shalat. Pendapat ini pula yang disampaikan oleh Imam Mâlik (wafat 179 H/800 M) dan Imam Ahmad bin Hanbal (wafat 241 $\mathrm{H} / 855 \mathrm{M}$ ). Sedangkan menurut kelompok alra'yi, kondisi sakit boleh melakukan jama' antara dua shalat, tentu harus sesuai dengan syaratsyarat yang telah berlaku bagi musafir. Sementara menurut Imam Syâfi'i, kebolehan tersebut tidak sewaktu berada di rumah, kondisi demikian (berada di rumah) hanya boleh melakukan jama' shalat ketika dalam kondisi hujan (Abadi, 2005: 608-609).

Berdasarkan itu, shalat yang dilakukan tersebut merupakan bentuk shalat jama' shuriy (bukan jama' hakikiy), yakni melakukan shalat yang pertama di akhir waktu hingga waktu shalat selesai, kemudian melakukan shalat yang kedua di awal waktu. Jadi shalat tersebut dilaksanakan sesuai dengan waktunya masing-masing. Itu terjadi karena melaksanakan shalat di luar waktu yang telah ditentukan tanpa ada 'udzur, merupakan perbuatan yang dilarang sesuai dengan kesepakatan ulama. Sementara di antara 'udzur yang membolehkan jama' shalat adalah rasa takut (khauf), perjalanan (safar) dan hujan (mathar) (al-Qurthubi, 1997: 346-347; alMuradi, 1956: 334-347).

Dalam riwayat Imam Malik (wafat 179 H/800 M), redaksi hadis menggunakan في غير فوف ولا سفر , bahwa jama' yang dilaksanakan Rasulullah saw dalam kondisi bukan rasa takut dan bukan pula dalam kondisi perjalanan. Imam Malik menakwilkan kondisi tersebut dengan kondisi hujan. Menurut Abu al-'Abbâs, penakwilan itu dibatalkan karena terdapat riwayat shahih yang secara jelas menyatakan من غير خوف ولا مطر (al-Qurthubi, 1997: 347). Ini mempertegas, pada dasarnya dalam ajaran Islam tidak pernah menekan pemeluknya dalam suatu perintah maupun larangan. Islam tidak pernah memberikan beban pada pemeluknya kecuali sesuai dengan kemampuannya (QS alBaqarah/2:286). Oleh karena itulah al-Qur'an menjelaskan bahwa dalam suatu kesulitan pasti terdapat kemudahan (QS al-Insyirah/94:5-6). Berdasarkan itu, para ulama membuat satu rumusan: المشقة تجلب التيسير (keadaan yang menyulitkan akan mendatangkan kemudahan).

Shalat jama' merupakan salah satu bentuk rukhshah apabila merasa ada kesulitan (masyaqqah) dalam mengerjakan shalat sesuai dengan waktu yang telah ditentukan. Rukhshah boleh dilaksanakan, apabila terdapat sebabsebab yang dibenarkan oleh syarit. Dengan demikian, tanpa sebab yang dibenarkan oleh syari, rukhshah tidak boleh dilaksanakan. Karena, itu mengindikasikan bahwa orang tersebut malas menuaikan kewajiban maupun meninggalkan larangan. Sifat malas dalam mengerjakan perintah shalat termasuk salah satu indikator (ciri) sikap orang munafiq (QS alNisa'/4:142-143).

Dengan demikian, hadis tersebut dapat dipahami bahwa pelaksanaan shalat jama' harus berdasarkan 'uzur yang membolehkannya, seperti kondisi perjalanan, sakit, dan hujan. Tanpa 'uzur tersebut, maka pelaksanaan shalat harus sesuai dengan waktunya. Sebab, pelaksanaan shalat jama' jika tidak disertai 'uzur, maka hal ini tentu akan bertentangan dengan ketentuan-ketentuan yang terdapat dalam ayat- 
ayat al-Qur'an, bahwa shalat merupakan suatu kewajiban bagi orang-orang beriman yang memiliki waktu yang telah ditentukan (QS alNisa/4:103). Paling tidak, hadis yang secara tekstual bertentangan dengan ayat al-Qur'an tersebut dapat dikompromikan (al-jam'u wa altaufîq) dengan cara mentakwil hadis itu kepada makna yang lebih sesuai atau sejalan dengan makna ayat al-Qur'an (haml al-zha>hir 'ala almuhtamal al-marjuh).

\section{Mengqadha Shalat Bagi Yang Meninggal}

Kewajiban qadha ini mengukuhkan bahwa bagaimanapun dan dalam kondisi apapun shalat fardhu tidak boleh ditinggalkan, kecuali bagi perempuan haidh. Lalu bagaimana dengan orang yang sudah meninggal? Apakah ahli waris atau keluarganya dianjurkan untuk mengqadha shalat orang yang sudah wafat? Persoalan ini sudah dibahas dan diperdebatkan oleh para ulama sejak dahulu. Dalam Fath al-Mu'in, Zainuddin alMalibari mengatakan:

$$
\text { قول من مات وعليه صلاة فرض لم تقض ولم تفد عنه ، وفي }
$$

“Orang yang sudah meninggal dan memiliki tanggungan shalat fardhu, tidak diwajibkan qadha dan tidak pula bayar fidyah. Menurut satu pendapat, dianjurkan qadha', baik diwasiatkan maupun tidak, sebagaimana diceritakan al'Abadi dari al-Syafi'i karena ada khabar mengenai persoalan ini. Bahkan, al-Subki melakukan qadha shalat untuk sebagian sanak familinya" (al-Dimyathi, tth: 24).

Memang tidak terdapat hadis yang secara tegas menunjukkan kebolehan qadha shalat bagi yang meninggal. Ulama yang membolehkan hal ini berdalil pada hadis kewajiban qadha puasa bagi ahli waris. 'Aisyah pernah mendengar Rasulullah saw bersabda: من مات و عليه صيام صام المام عنه وليه "Siapa yang meninggal dan memiliki tanggungan puasa, wajib bagi keluarganya untuk mengqadhanya" (Riwayat al-Bukhari). Anjuran mengqadha puasa ini disematkan pada shalat, karena keduanya sama-sama 'ibadah badaniyah (ibadah fisik). Dalam Syarah Shahih Muslim, al-Nawawiy (wafat 676 H/1277 M) juga menguraikan perdebatan ulama terkait hal ini. Persoalannya, apakah ibadah yang dilakukan orang yang masih hidup, pahalanya sampai kepada orang yang meninggal atau tidak?

Al-Nawawiy menjelaskan:

$$
\text { ذهب جماعات من العلماء إلى أنه يصل إلى الميت ثواب }
$$
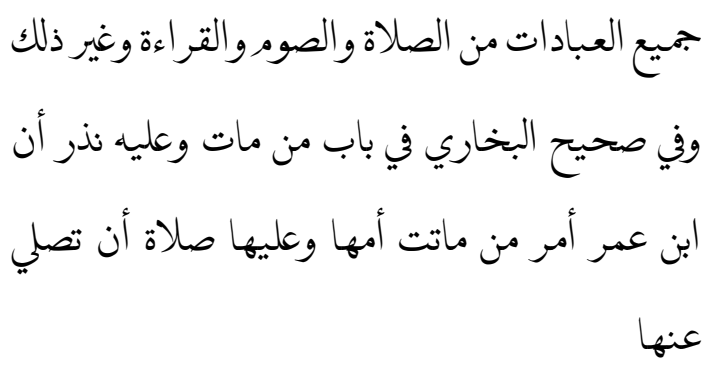

"Sekelompok ulama berpendapat bahwa pahala seluruh ibadah (yang dihadiahkan kepada orang yang meninggal) sampai kepada mereka, baik ibadah shalat, puasa, dan membaca al-Qur'an. Dalam Shahih al-Bukhari, bab orang yang meninggal dan masih memiliki kewajiban nadzar, bahwasanya Ibn 'Umar memerintahkan kepada seorang perempuan yang ibunya meninggal, serta memiliki tanggungan shalat, agar mengerjakan shalat untuk ibunya."

Kitab Fath al-Muin menyebutkan bahwa alSubki pernah mengqadha shalat untuk keluarganya yang sudah meninggal. Zainudin alMalibari (wafat 987 H/1579 M) menyatakan bahwa perbuatan mengqadha shalat tersebut terdapat dalam khabar, pendapat sahabat. Namun, Zainudin al-Malibari tidak menyebutkan dengan jelas apa khabaryang dimaksud itu. Karenanya, Abu Bakar Muhammad Syatha alDimyathi $(1310 \mathrm{H} / 1892 \mathrm{M})$, penulis I'anah alThalibin menjelaskan bahwa khabar itu antara lain disebutkan dalam Shahih al-Bukhari (alDimyathi, tth: 24). Berikut khabar tersebut:

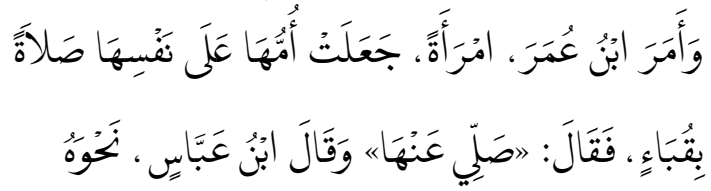

"Sahabat Ibnu Umar pernah menyuruh seorang perempuan untuk mengqadha shalat ibunya yang pernah ditinggal. Waktu itu ibunya 
bernazar untuk melakukan shalat di Masjid Quba, namun meninggal sebelum melakukannya. "Qadhakanlah nadzar shalat ibumu itu," perintah Ibn 'Umar pada perempuan tersebut. Hal ini juga merupakan pendapat yang disampaikan Ibn "Abbas."

Terkait pendapat sahabat Ibn 'Abbas, Imam Ibn Hajar berpendapat bahwa perempuan itu juga diperintah untuk berjalan kaki menuju Masjid Quba sebagaimana nadzar yang dilakukan ibunya. Selain itu, Imam Ibn Hajar juga mengutip pendapat Ibn al-Munir, yang dimaksud صَلِّي عَنْهَ di atas adalah shalat biasa, bukan shalat qadha. Namun demikian, amal shalat yang dilakukan perempuan itu pahalanya dapat dihadiahkan untuk mengganti nadzar shalat ibunya yang belum sempat dilakukan. Ibn al-Munir menambahkan, kasus seperti ini hanya khusus dapat dilakukan oleh anak untuk menggantikan ibadah orangtuanya. Oleh karena itu, selain anak orang yang bersangkutan, maka tidak dibolehkan (kharish, 2017).

Atas dasarkhabarini, Abu Bakar Muhammad Syatha al-Dimyathi menyampaikan bahwa sekelompok ulama Syafi'iyyah membolehkan qadha shalat untuk orang yang sudah meninggal. Selain itu, Abu Bakar Muhammad Syatha al-Dimyathi juga mengutip perkataan Ibn Burhan bahwa qaul qadim (pendapat Imam Syafi'i ketika di Irak) menyatakan bahwa ahli waris orang yang meninggal itu wajib mengqadha shalat yang ditinggalnya. Dalam pendapat lain di kalangan ulama Syafi'iyyah, ahli waris hanya diwajibkan memberi fidyah dengan satu mud (3/4 liter) beras untuk fakir-miskin sebagai ganti dari shalat yang ditinggal orang yang meninggal. Jadi setiap satu shalat fardhu yang ditinggal itu dibayar dengan beras satu mud. Semakin banyak shalat yang sempat ditinggal oleh salah satu anggota keluarga yang meninggal, maka semakin banyak pula fidyah yang dibayarkan (alDimyathi, tth: 24).

Sebagian ulama berpendapat, orang yang meninggal dan ia memiliki tanggungan shalat fardhu atau shalat lainnya, tidak dapat diqadha. Karena hukum asal ibadah, tidak boleh digantikan atau diwakilkan orang lain. Kecuali jika ada dalil dari syariat yang membolehkan untuk mewakilkan amal ibadah tertentu, seperti haji, menyalurkan zakat, sedekah, atau nadzar puasa. Sedangkan shalat fardhu, tidak dijumpai adanya dalil yang membolehkan untuk diwakilkan ke yang lain.

Imam Malik (wafat 179 H/800 M) menyebutkan keterangan dari sahabat Ibn 'Umar yang mengatakan, أنه لا يصوم أحد عن أحد، (bahwasanya tidak boleh seseorang berpuasa menggantikan kewajiban puasa orang lain, tidak boleh pula seseorang shalat menggantikan kewajiban shalat orang lain) (Anas, 1406/1985). Mungkin yang dimaksud Ibn 'Umar adalah selain utang puasa nadzar, sebab untuk puasa nadzar dapat diqadha orang lain setelah ia meninggal. Oleh karena itu, orang yang telah meninggal dunia, sementara ia pernah meninggalkan shalat, baik karena sakit atau ketika sehat, tidak dapat diqadha oleh orang lain. Kewajiban keluarganya dalam hal ini adalah memperbanyak doa dan istighfar (memohonkan ampun) untuknya.

Apabila ibadah itu terkait dengan fisik (badan) seperti shalat dan puasa, maka menurut kesepakatan ulama, hal itu tidak boleh diwakilkan kepada orang lain. Berdasarkan penegasan al-Qur'an:

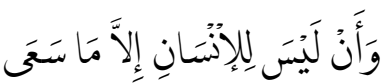

"Bahwasanya seorang manusia tidak memperoleh selain apa yang telah diusahakannya" (QS al-Najm/53:39).

Jika yang bersangkutan telah meninggal, maka menurut kalangan al- Hanafiyyah, alMalikiyyah, dan al-Syafi'iyyah (jumhur ulama) hukumnya tetaplah sama sebagaimana ia hidup, yakni shalatnya tidak boleh diwakilkan atau diqadha' oleh orang lain. Kecuali Ibn Abd alHakam dari kalangan al-Malikiyyah yang berpendapat bolehnya seseorang mengqadha' shalat yang ditinggalkan oleh orang yang meninggal semasa hidupnya (al-Raml, 1438/2017: 184-187).

Mayoritas ulama yang melarang hal tersebut beralasan bahwa mengqadha' shalat orang yang telah meninggal menafikan fungsi dari ibadah itu sendiri. Sebagaimana penjelasan Imam alSyatibi (wafat $790 \mathrm{H}$ ) dalam al-Muwafaqat (2/167), "Sesungguhnya tujuan dari ibadah adalah ketundukan kepada Allah, merendahkan diri di hadapanNya, tunduk taat pada hukumNya, serta memenuhi hati dengan dzikir kepadaNya, hingga seorang hamba dapat merasakan 
kehadiran dan pengawasan Allah dengan hati dan anggota badannya, serta tidak lalai dariNya. la selalu berusaha mengharapkan keridhaanNya, dan mendekatkan diri kepada Allah sesuai dengan kemampuannya. Sedangkan alniya $>$ bah (mewakilkan ibadah kepada orang lain) menafikan tujuan ini ... ." (al-Syaukani, tth: 359).

Kalangan ulama Hanafiyyah berpendapat, jika orang yang meninggal dan memiliki kewajiban mengqadha' shalat, sebelum meninggalnya berwasiat kepada wali atau ahli warisnya untuk mengqadha' shalatnya dengan kaffarat, maka wajib bagi mereka untuk melaksanakan wasiat tersebut berupa $1 / 2$ sha' $/ 2$ mud/12 ons dari makanan pokok atas setiap shalat yang ditinggalkan. Adapun kaffarat itu sendiri hanya dapat diambil dari $1 / 3$ harta yang ditinggalkannya sebagaimana ketentuan hukum wasiat yang hanya dibolehkan berwasiat maksimal 1/3 hartanya. Akan tetapi jika orang yang meninggal tidak pernah berwasiat untuk melakukan itu, maka gugurlah kewajiban shalat tersebut karena sebuah 'uzur (kematian) ('Abidin, tth: 237).

Ulama Hanafiyyah menyatakan, jika orang sakit meninggal dunia, dan di masa sakitnya tidak mampu melakukan shalat walaupun hanya dengan isyarat kepala, maka ia tidak wajib mewasiatkan tanggungan shalatnya kepada ahli waris meskipun sedikit. Siapa saja yang meninggal dunia dan belum mengqadha' shalatshalat yang ditinggalkannya tanpa 'udzur, seperti orang yang masih mampu melakukannya walaupun hanya dengan isyarat, maka ia wajib berwasiat agar membayar kaffarat sebagai penggantinya (Az-Zuhaili, 2010: 275).

Sebagian ulama Syafi'iyyah berpendapat, wali orang yang meninggal hendaknya memberikan fidyah atas setiap shalat yang ditinggalkan sebanyak 1 mud/6 ons dari makanan pokok. Pendapat ini tidak masyhur dalam madzhab Syafi'i (al-Raml, 1438/2017: 188). Sedangkan kalangan ulama Hanabilah membedakan antara shalat fardhu dan shalat nadzar. Untuk shalat fardhu mereka berpendapat, tidak dibolehkan mewakilkan shalat fardhu atas orang yang meninggal, sebab shalat fardhu tidak dapat diwakilkan semasa hidupnya, demikian pula setelah ia meninggal.
Adapun jika shalat nadzar, jika ia tidak mampu melakukannya karena sebuah 'udzur lalu meninggal, maka tidak perlu dibayar oleh ahli warisnya. Sedangkan jika pada asalnya ia mampu melakukan namun belum dilakukan hingga meninggal, maka disunnahkan bagi ahli warisnya untuk membayar nadzarnya. Bagi selain wali orang yang meninggal, dibolehkan membayar nadzarnya dengan izin ataupun tanpa izin dari orang yang meninggal semasa hidupnya (Syarh Muntaha al-Iradat 1/121, 417, 418, 457, 458).

Pendapat masyhur dalam madzhab Syafi'i menyebutkan bahwa ibadah shalat orang yang sudah wafat tidak dapat diqadha' oleh siapa pun, serta tidak dapat digantikan dengan pembayaran fidyah berupa menyedekahkan makanan pokok. Pendapat lain mengatakan bahwa shalat yang ditinggalkan oleh orang yang meninggal semasa hidupnya dapat diqadha'. Dalam qaul qadim (fatwa lama), Imam al-Syafi'i berpandangan bahwa wali orang yang meninggal (anak, saudara, dan lain-lain) wajib mengqadha' shalat orang yang meninggal, walaupun ia meninggalkan harta warisan (tirkah). Sedangkan pendapat terakhir (qaul jadid) menyebutkan bahwa setiap shalat fardhu yang ditinggalkan oleh orang yang meninggal digantikan dengan pembayaran fidyah (pemberian makanan pokok) kepada fakir miskin sebesar 1 mud (0,6 kilogram atau 3/4 liter) makanan pokok. Perbedaan pendapat tentang hal ini dijelaskan oleh Abu Bakar Muhammad Syatha al-Dimyathi dalam kitab l'anat alThalibin, Juz 1, h. 24 sebagai berikut:

$$
\begin{aligned}
& \text { من مات وعليه صلاة ، فلا قضاء، ولا فدية. وفي قول - } \\
& \text { كجمع ججتهدين - أنها تقضى عنه، لخبر البخاري } \\
& \text { وغيره، ومن ثم اختاره جمع من أئمتنا، وفعل به } \\
& \text { السبكي عن بعض أقاربه، ونقل ابن برهان عن القديم } \\
& \text { أنه يلزه الولي - إن خلف تركه- أن يصلي عنه. } \\
& \text { كالصوم. وفي وجه - عليه كثيرون من أصحابنا - أنه } \\
& \text { يطعم عن كل صلاة مدا. وقال المحب الطبري: يصل }
\end{aligned}
$$


للميت كل عبادة تفعل عنه: واجبة أو مندوبة. وفي ثرح المختار لمؤلفه: مذهب أهل السنة أن للانسان أن يبجعل ثواب عمله وصلاته لغيره ويصله ( أبو بكر محمد ثطا الدمياطى، إعانة الطالبين، الجزء الأول ، صفحة ). (1) ).

Qaul jadid Imam Syafi'i ini didasarkan pada keterangan hadis:

لا يصلى أحد عن أحد ، ولا يصوم أحد عن أحد ، ولكن

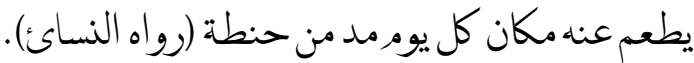

"Seseorang tidak boleh melakukan shalat untuk orang lain, dan seseorang tidak boleh melakukan puasa untuk orang lain, tetapi harus memberi makan sebagai gantinya setiap hari dengan satu mud gandum" (Riwayat al-Nasa'i).

Imam al-Muhib al-Thabari (wafat 310 H/923

M) berpendapat bahwa setiap ibadah yang dilakukan untuk orang yang meninggal, baik berupa ibadah wajib ataupun ibadah sunnah dapat sampai padanya. Dalam kitab Syarah alMukhtar dijelaskan: “Madzhab Ahl al-Sunnah wa al-Jama'ah berpandangan bahwa seseorang dapat menjadikan pahala amal dan shalatnya untuk orang lain dan pahala tersebut bisa sampai padanya" (al-Dimyathi, tth: 24).

Salah satu ulama Syafi'iyah yang berpandangan bahwa shalat yang ditinggalkan oleh orang yang meninggal dapat digantikan dengan memberi makanan satu mud adalah Imam al-Baghawi (wafat 516 H/1122 M). la menjelaskan dalam kitab al-Majmu' 'ala Syarh alMuhadzdzab:

لو مات وعليه صلاة أو اعتكاف لم يفعلهما عنه وليه

ولا يسقط عنه بالفدية صلاة ولا اعتكاف هذا هو

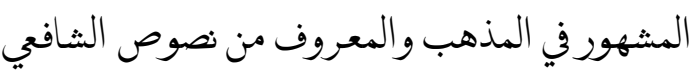

في الام وغيره ونقل البويطي عن الثـافي أنه قال في

الاعتكاف يعتكف عنه وليه وفىرواية يطعم عنه قال

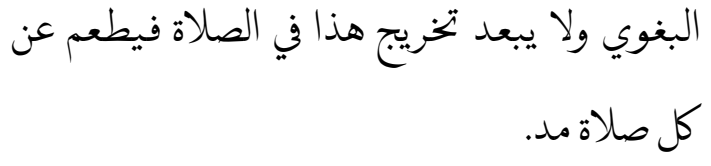

"Jika seseorang meninggal dan ia memiliki tanggungan shalat atau i'tikaf yang belum ia lakukan, maka pihak wali orang yang meninggal tidak dapat melakukan kedua ibadah tersebut sebagai ganti atas orang yang meninggal itu, dan membayar fidyah pun tidak menggugugurkan tanggungan shalat dan i'tikafnya. Pendapat ini merupakan pendapat yang masyhur dalam madzhab Syafi'i dan pandangan yang terkenal dalam nash Imam alSyafi'i dalam kitabal-Um dan kitab yang lain. Imam al-Buwaithi menukil dari Imam alSyafi'i bahwa ia berpandangan tentang i'tikaf dapat digantikan oleh pihak wali, sedangkan dalam sebagian riwayat digantikan dengan memberi makanan (fidyah) atas ganti tanggungan i'tikaf orang yang meninggal. Imam al-Baghawi berkata: tidak jauh untuk memberlakukan hal ini dalam shalat, maka pihak wali memberi makanan (fidyah) satu mud atas setiap shalat" (al-Nawawi, tth: 372).

Pandangan bahwa shalat orang yang meninggal dapat digantikan dengan fidyah ini, sesuai dengan salah satu hadis mauquf dari sahabat Ibn 'Abbas:

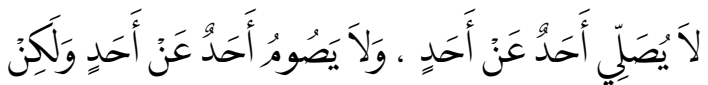

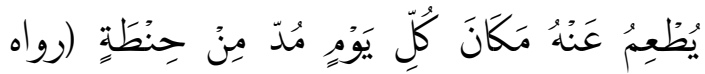<smiles>C1=C[As][As]1</smiles>

"Seseorang tidak dapat shalat untuk menggantikan shalat orang lain, dan tidak dapat puasa sebagai ganti atas puasa orang lain, tetapi ia dapat memberi makan sebagai ganti (shalat atau puasa) orang lain, setiap hari satu mud dari gandum" (Riwayat al-Nasa'i).

Selain dalam madzhab Syafi'i, penggantian shalat yang ditinggalkan oleh orang yang meninggal dengan membayar fidyah juga merupakan pendapat yang mu'tabar dalam madzhab Hanafi. Namun dalam hal ini, para ulama Hanafiyyah berpendapat bahwa shalat 
yang ditinggalkan oleh orang yang meninggal dapat digantikan dengan pembayaran fidyah hanya ketika orang yang meninggal itu mewasiatkan untuk pembayaran fidyah atas shalat yang ia tinggalkan. Jika ia tidak mewasiatkan tentang pembayaran fidyah ini, maka para ulama Hanafiyyah tidak berpandangan bahwa pembayaran fidyah dapat menggantikan shalat yang ditinggalkan oleh orang yang meninggal, kecuali menurut pandangan Muhammad bin Hasan yang mengatakan bahwa pembayaran fidyah tetap dapat mengganti atas shalat yang ditinggalkan oleh orang yang meninggal, meskipun ia tidak mewasiatkannya.

Pembayaran fidyah dalam madzhab Hanafi ini dapat memilih di antara dua komoditas, yaitu setengah sha' (1,9 kilogram) gandum/tepung atau satu sha' (3,8 kilogram) kurma atau anggur. Namun wali orang yang meninggal juga dapat mengeluarkan fidyah dengan bentuk nominal uang yang setara dengan harga salah satu dari dua pilihan pembayaran tersebut, sehingga secara umum dapat dipahami bahwa pembayaran fidyah menurut mazhab Hanafi ini relatif lebih besar takarannya jika dibandingkan pembayaran fidyah dalam madzhab Syafi'i.

Pandangan madzhab Hanafi mengenai persoalan fidyah shalat ini, dijelaskan secara rinci dalam kitab al-Mausu'ah al-Fiqhiyyah alKuwaitiyyah:

ذهب جمهور الفقهاء " المالكيّة والثّافعيّة والحنابلة " إلى أنّ الصّلاة لا تسقط عن الميّت بالإطعام. وذهب " الحنفيّة إلى أنّه إذا مات المريض ولم يقدر على أداء

الصّلاة بالايماء برأسه لا يلزمه الإيصاء بها. أمّا إذا كان قادراً على الصّلاة ولو بالإيماء وفاتته الصّلاة بغير عذر لزمه الإيصاء بالكفّارة عنها ، فيخرج عنه وليّه من ثلث التّركة للكّ صلاة مفروضة ، وكذا الوتر لأنّه فرض عمليّ عند أبي حنيفة. وقد ورد النّصّ في الصّياه ، وهو قوله صلى الله عليه وسلم : ” ولكن

$$
\begin{aligned}
& \text { يطعم عنه ه والصّلاة كالصّياه باستحسان المشايخ } \\
& \text { لكونها أهمّ. و والصّحيح : اعتبار كلّ صلاة بصوم يوه } \\
& \text { ، فيكون على كلّ صلاة فدية ، وهي نصف صاع من برّ } \\
& \text { أو دقيقه أوسويقه ، أو صاع تمر أو زبيب أوشعير أو } \\
& \text { قيمته ، وهي أفضل لتنوّع حاجات الفقير. وإن لم } \\
& \text { يوص وتبرّع عنه وليّه أو أجنبيّ جاز إن ثـاء اللهّ تعالى } \\
& \text { عند محمّد بن الحسن وحده لأثّه قال في تبرّع الوارث } \\
& \text { بالاطعاه في الصّوم يجزيه إن ثناء الله تعالى من غير } \\
& \text { جزم. وفي إيصائه به جزمر الحنفيّة بالاجززاء }
\end{aligned}
$$

“Mayoritas ulama fiqih (Malikiyyah, Syafi'iyyah, dan Hanabilah) berpandangan bahwa shalat tidak gugur atas orang yang meninggal dengan memberi makan (pada orang lain). Sedangkan ulama Hanafiyyah berpandangan bahwa ketika orang yang sakit meninggal, dan ia sebelumnya tidak mampu untuk melaksanakan shalat dengan berisyarat dengan kepalanya, maka ia tidak wajib untuk mewasiatkan tentang shalat yang tertinggal tersebut. Jika ia mampu untuk melakukan shalat, walaupun dengan berisyarat, dan shalatnya tidak ia laksanakan dengan tanpa adanya uzur, maka wajib baginya untuk mewasiatkan pembayaran kaffarat (denda) atas shalat tersebut. Pihak wali orang yang meninggal mengeluarkan harta dari sepertiga harta peninggalan orang yang meninggal itu untuk setiap shalat fardhu yang ditinggalkan. Begitu juga untuk shalat witir, sebab shalat witir merupakan amaliah fardhu menurut Imam Abu Hanifah. Dalil nash yang menjelaskan tentang fidyah ini terdapat pada permasalahan puasa, yakni sabda Rasulullah saw: 'Tetapi (wajib) memberi makanan sebagai ganti dari puasa', sedangkan shalat sama persis dengan puasa atas jalan istihsan (anggapan baik) masyayikh (ulama figh Hanafiyyah), sebab shalat dipandang lebih penting. Menurut qaul 
shahih, setiap shalat disamakan seperti puasa satu hari, maka setiap satu shalat fardhu satu fidyah, yakni setengah sha' dari gandum atau tepung atau gandum kecil; atau satu sha' dari kurma, anggur, jerawut, atau harga dari komoditas tersebut. Memberi fakir miskin dengan nominal harga dari komoditas tersebut dipandang lebih utama, sebab beraneka ragamnya kebutuhan orang-orang fakir. Jika orang yang meninggal tidak mewasiatkan tentang shalat yang ia tinggalkan, lalu pihak wali orang yang meninggal atau orang lain bertabarru' (lepas tanggung jawab) untuk membayarkan fidyah, maka hal tersebut insya Allah diperbolehkan hanya menurut pandangan Muhammad bin Hasan saja. Sebab ia berpandangan bahwa tabarru'nya wali untuk memberikan fidyah (makanan) atas puasa orang yang meninggal adalah hal yang mencukupinya insya Allah dengan tanpa adanya kemantapan (bimbang). Sedangkan dalam permasalahan ketika orang yang meninggal ini mewasiatkan tentang membayar fidyah, maka ulama Hanafiyyah mantap untuk berpandangan mencukupi bagi ibadah (shalat atau puasa) orang yang meninggal" (Kementerian Wakaf dan Urusan Agama Kuwait, 1983: 83).

\section{PENUTUP}

\section{Simpulan}

Perawi yang meriwayatkan hadis 'menjama' shalat tanpa halangan" dalam Sunan Abu Daud nomor 1025 secara keseluruhan berkualitas tsiqah, shaduq, hafizh li al-hadits, serta ahl al'ilm. Totalitas nilai para perawi dari jalur Abu Daud dan adanya mu'ashsharah serta liqa' dapat dijadikan bukti bahwa jalur sanad Abu Daud ini bersambung mulai dari mukharrij hingga sampai pada Rasulullah saw. Sedangkan dari segi kuantitas perawi, hadis tersebut menjadi hadîs ahad 'azîz. Hal ini, karena jumlah perawi dalam tiap tingkatannya lebih dari dua orang, yakni dua orang di thabaqah sahabat, kemudian diteruskan dengan jumlah perawi yang banyak pada setiap tingkatannya sampai pada mukharrij hadits.
Menjama' shalat adalah rukhshah, yakni kemudahan yang diberikan Allah. Karena itu, pelaksanaanya harus ada sebab yang membolehkan. Safar, sakit, rasa takut dan hujan merupakan di antara beberapa sebab yang memperbolehkan menjama' shalat. Hadis riwayat Abu Dawud nomor indeks 1025, secara redaksional memang mengisyaratkan kebolehan menjama' shalat tanpa sebab atau halangan, namun jika dipahami demikian, maka akan bertentangan dengan QS al-Nisâ'/4:103 yang menyatakan bahwa shalat merupakan kewajiban yang ditetapkan bagi orang-orang yang beriman yang telah ditentukan waktunya. Dengan demikian, hadis tersebut ditakwil bahwa ketika Rasulullah saw menjama' shalat, beliau dalam kondisi sakit, atau kondisi hujan atau mendung.

Berkenaan dengan masalah qadha shalat, jika ibadah itu terkait dengan badan (fisik) seperti shalat dan puasa, maka menurut kesepakatan ulama, hal itu tidak boleh diwakilkan kepada orang lain (QS al-Najm/53:39 dan keterangan dari Ibn 'Umar). Apabila yang bersangkutan telah meninggal, menurut kalangan jumhur ulama (Hanafiyyah, Malikiyyah, dan Syafi'iyyah) hukumnya tetap sama seperti ia hidup, yakni shalatnya tidak boleh diwakilkan atau diqadha' oleh orang lain. Ibn Abd al-Hakam dari kalangan Malikiyyah dan sebagian ulama Syafi'iyyah berpendapat, dibolehkan bagi seseorang mengqadha' shalat yang ditinggalkan oleh orang yang meninggal semasa hidupnya.

Pembayaran fidyah merupakan salah satu dari pandangan para ulama tentang hal yang dapat menggantikan shalat yang telah ditinggalkan oleh orang yang meninggal. Cara pembayaran fidyah jika berpedoman pada madzhab Syafi'i yaitu dengan memberi makanan pokok senilai 1 mud (0,6 kilogram atau 3/4 liter) kepada fakir miskin sebagai pengganti setiap satu shalat yang ditinggalkan oleh yang meninggal. Sedangkan menurut madzhab Hanafi, pembayaran fidyah dapat berupa salah satu di antara dua pilihan, yakni setengah sha' (1,9 kilogram) gandum atau tepung atau satu sha' (3,8 kilogram) kurma atau anggur. Wali orang yang meninggal (anak, saudara, dan lainlain) juga dapat mengeluarkan fidyah dengan bentuk nominal uang yang setara dengan harga salah satu dari dua pilihan pembayaran fidyah. Mayoritas fuqaha dari kalangan Malikiyyah, 
Syafi'iyyah, dan Hanabilah berpandangan, shalat tidak gugur atas orang yang meninggal dengan memberi makan (pada orang lain). Perbedaan pendapat di kalangan ulama figh, disebabkan tidak terdapat penjelasan dalam al-Qur'an maupun Sunnah yang bersifat qath'i. Dari sinilah ulama melakukan ijtihad yang kebenarannya relatif (zhanniy). Keberadaan ilmu mukhtalif alhadits adalah sangat urgen dalam ijtihad untuk mencari solusi penetapan hukum yang tepat dan representatif.

\section{Rekomendasi}

Pusdiklat Tenaga Teknis Pendidikan dan Keagamaan harus memfasilitasi kajian-kajian keislaman khususnya berkaitan dengan kajian hadis, tafsir, hukum Islam, ushul figh dan lainlain untuk pengembangan kompetensi widyaiswara.

Menghidupkan budaya diskusi, bedah buku, dan seminar hendaklnya menjadi program yang didukung institusi, bukan hanya formalitas dan bersifat temporer. 


\section{DAFTAR PUSTAKA}

Abâdî, Abi 'Abd al-Rahmân Syaraf al-Haq al-'Azhîm, 'Aûn al-Ma'bûd 'Alâ Syarh Sunan Abî Dâud, Beirut: Dâr lbn Hazm, 2005, Jilid 1.

‘Abidin, Ibn, Radd al-Mukhtar ‘ala Dar al-Mukhtar, Mesir: Musthafa al-Babi al-Halabi, Juz 1.

'Ainiy, Badr al-Din Abu Muhammad Mahmud bin Ahmad al, 1972, Umdah al-Qariy Syarh Shahih al-Bukhariy, Aleppo: Mustafa al-Babiy al-Halabiy.

Ali, Nizar, 2001, Memahami Hadis Nabi (Metode dan Pendekatan), Yogyakarta: Center for Educational Studies and Development (CESaD) YPI Al-Rahmah.

Anas, Malik bin, Al-Muwaththa', (Beirut: Dar Ihya' al-Turats al-'Arabiy, 1406 H/1985 M, Juz 1, Bab Shalat.

Andalusiy, Muhammad bin Ahmad bin Muhammad bin Ahmad bin Rusyd al-Qurthubiy al, Bidayat al-Mujtahid, Indonesia: Dar Ihya al-Kutub al-'Arabiyah, tth., Juz 1.

'Asqalaniy, Ahmad bin 'Ali bin Hajar al, Fath al-Bariy bi Syarh Shahih al-Bukhariy, Kairo: Dar al-Hadits, 2004 M/1424 H, Juz 2 dan Juz 3.

Buthi, Sa'id Ramadhan al, Mabahits al-Kitab wa al-Sunnah, Damsyiq: Mahfuzhah li al-Jami'ah, tth.

Dimyathi, Abu Bakar Muhammad Syatha al, I'anat al-Thalibin, Indonesia: Dar Ihya'al-Kutub al-'Arabiyah, tth., Juz 1.

Ismail, M. Syuhudi, Kaedah Kesahihan Sanad Hadis, Jakarta: Bulan Bintang, 1988, Cet. ke-1.

Kementerian Wakaf dan Urusan Agama Kuwait, Al-Mausu'ah al-Fiqhiyyah al-Kuwaitiyyah, Kementerian Wakaf dan Ururusan Agama Kuwait, 1983, Juz 25, Cet. ke-2.

Kharish, Ibnu, 2017, "Hukum Mengqadha Shalat Orang Meninggal," https://bincangsyariah.com/ubudiyah/hukum-mengqadha-shalat-orang-meninggal/, diakses 20 April 2020.

Khatib, Muhammad ‘Ajjaj al, Ushul al-Hadits ‘Ulumuh wa Musthalahuh, Beirut: Dar al-Fikr, 1989.

Khayyath, Usamah bin 'Abdullah, 2001, Mukhtalif al-Hadits baina al-Muhadditsain wa al-Ushuliyyin al-Fuqaha', Beirut: Dar Ibn Hazm.

Khithâbî, Abi Sulaimân Ahmad bin Muhammad al, Ma'âlim al-Sunan, tth., Juz 1.

M., Buchari, 1999, Metode Pemahaman Hadis, Sebuah Kajian Hermeneutik, Jakarta: Nuansa Madani.

Muradi, Ali bin Sulaiman al, Al-Inshaf fi Ma'rifat al-Rajih min al-Khilaf, Mathba'ah al-Sunnah al-Muhammadiyyah, 1956. Juz 1.

Mutakin, Ali, “Menjama' Shalat Tanpa Halangan: Analisis Kualitas dan Kuantitas Sanad Hadits," Jurnal Kordinat, Vol. XVI, No. 1, April 2017.

Nawawiy, Abu Zakariyya Yahya bin Syaraf al, Shahih Muslim bi Syarh al-Nawawiy, Mesir: al-Mathba'at Mishriyyah, tth., Juz 1. , Abu Zakariyya Muhyi al-Din bin Syaraf al, Al-Majmu' Syarh al-Muhadzdzab, Idarah al-Thiba'iyah alMuniriyah, tth., Juz 6.

Qurthûbi, Abî al-‘Abbâs Ahmad bin 'Umar bin Ibrâhim al, Al-Mufhim Limâ Asykala Min Talkhîsh Kitab Muslim, Beirut: Dâr lbn Katsir, 1997, Jilid 2.

Raml, Al-Syamsu al, Nihayat al-Muhtaj al-Syarh al-Minhaj, Kairo: Dar al-Hadits, 2017 M/1438 H, Juz 3. 
Sabiq, Al-Syeikh Al-Sayyid, Fiqh al-Sunnah, Beirut: Dar al-Fikr, 1981 M/1401 H, Jilid 1, Cet. ke-3.

Shiddieqy, Muhammad Hasbi Ash, Koleksi Hadis-Hadis Hukum, Semarang: Pustaka Rizki Putra, 2001, Jilid 4, Cet. ke-3.

Suyuthi, Muhammad bin Abu Bakar al, Tadrib al-Rawi fi Syarhi Taqrib al-Nawawi, (Beirut: Dar al-Kutub al‘llmiyah, 1992), Juz 1.

Syaukaniy, Muhammad bin 'Ali bin Muhammad al, Nail al-Authar, Beirut: Dar Ibn Hazm, 2000 M/1421 H, Cet. ke1.

Syaukaniy, Muhammad bin ‘Ali al, Fath al-Qadir, Mesir: Dar al-`Alamiyah, Juz 2.

Thahhan, Mahmud al, 1405, Taisir Musthalah al-Hadits, Iskandariyah: Markaz al-Huda al-Dirasat.

Tim Baitul Kilmah, Ensiklopedia Pengetahuan Al-Qur'an dan Hadits, Jakarta: Kamil Pustaka, 2017, Jilid 2, Cet. ke3.

Wahab, Muhammad Abdul, "Hadits-hadits yang saling bertentangan," https://www.rumahfiqih.com/fikrah-220hadits-hadits-yang-saling-bertentangan.html, diakses 8 Oktober 2020.

Yusqi, Moh. Ishom, Metodologi Penyelesaian Hadits Kontradiktif, Ciputat: Sukses Bersama, 2010, Cet. ke-5.

Zuhaili, Wahbah Az, Prof. Dr., Fiqih Islam Wa Adillatuhu, terjemahan Al-Fiqh al-Islamiy wa Adillatuh, Jakarta: Gema Insani, 2010, Jilid 2, Cet. ke-1. 